\title{
The Dialectical Imagination of Maxine Greene: Social Imagination as Critical Pedagogy
}

Wendy Kohli

Fairfield University, wkohli@fairfield.edu

Follow this and additional works at: https://digitalcommons.fairfield.edu/education-facultypubs Copyright 2016 Purdue University

\section{Peer Reviewed}

\section{Repository Citation}

Kohli, Wendy, "The Dialectical Imagination of Maxine Greene: Social Imagination as Critical Pedagogy" (2016). GSEAP Faculty Publications. 128.

https://digitalcommons.fairfield.edu/education-facultypubs/128

\section{Published Citation}

Kohli, Wendy. "The Dialectical Imagination of Maxine Greene: Social Imagination as Critical Pedagogy." Education and Culture 32, no. 1 (2016): 15-24.

This item has been accepted for inclusion in DigitalCommons@Fairfield by an authorized administrator of DigitalCommons@Fairfield. It is brought to you by DigitalCommons@Fairfield with permission from the rightsholder(s) and is protected by copyright and/or related rights. You are free to use this item in any way that is permitted by the copyright and related rights legislation that applies to your use. For other uses, you need to obtain permission from the rights-holder(s) directly, unless additional rights are indicated by a Creative Commons license in the record and/or on the work itself. For more information, please contact digitalcommons@fairfield.edu. 


\section{PROJECT MUSE}

The Dialectical Imagination of Maxine Greene: Social Imagination as Critical Pedagogy

Wendy Kohli

Education and Culture, Volume 32, Number 1, 2016, pp. 15-24 (Article)

Published by Purdue University Press

$\Rightarrow$ For additional information about this article https://muse.jhu.edu/article/621285 


\section{The Dialectical Imagination of MaXine Greene: Social Imagination as Critical Pedagogy}

\section{Wendy Kohli}

\section{SituATing THE CONVERSATION}

Over 25 years ago, 1988 to be exact, Maxine Greene delivered the annual John Dewey Lecture. That lecture, “The Dialectic of Freedom," was the foundation for her book of the same title, also published in 1988 by Teachers College Press. In his foreword to the book, the late Bob Gowin, a philosopher of education at Cornell University, introduced the text with the following:

Many dialectics are working in this beautifully written book, and no single formulation will capture the whole. It is a book about social freedom based on naming and resisting and overcoming obstacles in order to achieve freedom. It is a book on social imagination, speculative audacity, and intimations of power over our futures (Greene 1988, ix).

I want to echo his words by saying that I, too, have no single formulation to capture the whole meaning of Greene's work on the imagination. This essay offers a critical reflection and contextualization of that concept, as embodied in and through Greene's multidisciplinary writings. In a way, I will be “doing philosophy” on Greene's work as she has defined it.

For those familiar with Greene's approach to philosophy, it is an understatement to say that she was not one for crisp analytic-conceptual analysis. Rather, she embodies and contextualizes concepts through historical, literary, and artistic references. The same can be said for her resistance to propositional arguments; they appear rarely in her work.

Looking back to one of her earliest books, Teacher as Stranger: Educational Philosophy for the Modern Age, Greene tells us that for her, as an existential phenomenologist, "to do philosophy, then, is to become highly conscious of the phenomena of events in the world as [presented] to consciousness ... to develop a fundamental project, to go beyond the situations one confronts and refuse reality as given in the name of a reality to be produced" (Greene 1973, 7). 


\section{W. KOHLI}

This is not to say that she completely eschewed clarifying meanings. In fact she says in the same breath, "to do educational philosophy is to become critically conscious of what is involved in the complex business of teaching and learning ... to clarify the meanings of education ..." (Greene 1973, 7). She insists that it is important for teachers to do this because "if [she] can learn to do philosophy, [she] may liberate [herself] for understanding and for choosing. [She] may liberate [herself] for reflective action as someone who knows who [she] is as a historical being, acting on [her] freedom, trying each day to be" (Greene 1973, 7).

In addition to existentialism and phenomenology, Greene's approach to philosophy was influenced greatly by John Dewey's pragmatism. We see this, for example, in Teacher as Stranger when Greene cites Dewey to support her views:

Dewey treated philosophy as an activity, a way of thinking about what was known and valued rather than as a body of doctrines or truths. Philosophy was to be carried on in the situations of an open, challenging, perplexing world in which human hopes could never be finally realized. It was linked to the cause of growth and the cause of progress, both of which were to be pursued amid continuities and change (Greene 1973, 36-37; emphasis added).

It is with this understanding of Greene's approach to philosophy of education that I share my reflections on her concept of the social imagination, including its connection to Dewey's work on aesthetics and Freire's views on critical pedagogy.

First, I need to pay some attention to Greene's use of "the dialectic," since as is typical, her application of this concept is fluid. Here I quote:

It is a matter of affirming human beings as 'subjects of decisions' rather than objects, of involving men and women striving toward their own 'completion'-a striving than can never end... . It is with a similar concern for the human vocation and for situatedness that I speak of 'the dialectic of freedom' ... I am eager to reaffirm the significance of desire along with the significance of thought and understanding; I want to break whenever possible, the persisting either/ors (Greene 1988, 8).

Clearly we are reminded of Dewey's dialectical thinking, especially in Experience and Education, where he argues for a theory of education based on a theory of experience that avoids "extreme opposites" and does not "formulat[e] its beliefs in Either/Ors" (Dewey 1938; 1997, 17). Greene insisted that:

There is, after all, a dialectical relation marking every human situation. ... This relation exists between two different, apparently opposite poles; but it presupposes a mediation between them ... what is suggested by the notion of mediation, [is] something that occurs between nature and culture, work and action, technologies and human minds (Greene 1988, 8). 
And she recognized that:

Always, there is a type of tension; but it is not the type of tension that can be overcome by a triumph of subjectivity or objectivity. Nor is it the kind of dialectic than can be resolved in some perfect synthesis or harmony (Greene 1988, 8; emphasis added).

For me, this passage embodies Greene's stance as a critical theorist/pedagogue, with strong existentialist and pragmatist leanings. Like Dewey, she wants to avoid thinking in either/or terms. And from Sartre, Camus, and Merleau-Ponty, Greene recognizes the importance of the context of our lived experience, and that this lived experience must be understood through our consciousness. She underscores that it is our situated consciousness that mediates our dialectical existence in the world; the dialectical relationship between subject and object.

It is crucial to reinforce that Greene, the existentialist, resists any kind of ending or resolution or completion-a resolution that Hegelian or Marxist dialectics might require. Instead, she reminds us in her writings that we are all always on a search for freedom, and for completion-a search that is never finished. I think here of that tender moment in Markie Hancock's now-classic film, "Exclusions and Awakenings: The Life of Maxine Greene," where Greene is walking back to her apartment on $5^{\text {th }}$ Avenue and a voiceover says, "I am, not yet" (Hancock 2001). She was at least 83 years old at that time! Yet still becoming ... So, let us continue in our search for understanding of Greene's dialectical imagination.

\section{Greene's Dialectical Imagination}

Over the course of Greene's lifetime of scholarly work, she argued that our received framework of critical rationality was not sufficient to understand (or transform) what she often called "the sedimented layers" of human experience-within educational systems or in the society at large. For Greene, these layers are barriers to educating for democracy, for social justice, and for human liberation. They require an expanded notion of critical reflection-one that incorporates rational, emotional, ethical, and aesthetic sensibilities - in order to come to more complete understanding. Like Greene, I agree that no single discourse can grasp adequately the complexities and contradictions of human experience in our contemporary multicultural world. Drawing on the existentialism and phenomenology of Merleau-Ponty, Greene embraced the "prereflective landscape" of each individual's situatedness as the foundation for understanding the world-however partial those perspectives would necessarily be (Greene 1988, 21). Similarly, Greene embraced Bahktin's concept of "heteroglossia" to allow for open dialogue and to create spaces "where multiple voices and multiple discourses intersect and interact” (Greene 1988, 129). 


\section{W. KOHLI}

To achieve this array of perspectives, of multiple voices, Greene, like Dewey, embraced the "potency of the arts" (Greene 2001, 196-197). It is worth quoting Dewey at length here-as Greene does-to make vivid the influence of his work on her aesthetic-political thinking:

The function of art has always been to break through the crust of conventionalized and routine consciousness. Common things, a flower, a gleam of moonlight ... not things rare and remote, are means with which the deeper levels of life are touched. ... This process is art... Artists have always been the real purveyors of news, for it is not the outward happening itself which is new, but the kindling by it of emotion, perception, and appreciation $^{1}$ (Dewey, as quoted in Greene 2001, 197).

Greene took seriously Dewey's understanding of the power of art to deepen the lives of people. It was clear from how she lived her life that she appreciated the beauty and meaning of art qua art. However, she also saw that painting, literature, music, drama, dance, photography, and film had the potential for rationalizing the status quo just as much as it could transform it. She also resisted sentimentalizing the imagination by reminding us that acts of horror have been committed because someone was able to imagine them and implement them. That is why it was important for Greene to emphasize the development of a critical consciousness of the world through a critical engagement with the arts (Greene 2001, 197). It is in this extension of Dewey's aesthetic experience that we see Greene's politicalphilosophical roots in existentialism and critical theory.

Greene's modernist grounding kept her focused on the critical, transformative possibilities of the arts. To support her position, she invoked Jean Paul Sartre who said: " it is on the day that we can conceive of a different state of affairs that a new light falls on our troubles and our suffering and that we decide that these are unbearable"' (Greene 1995, 5). For Greene, it is our social imagination at work when we see something as "unbearable," such as uncaring schools, and that we are able to "think of humane and liberating classrooms for every learner" (Greene 1995, 5). Greene readily admits that to attain this social imagination one must develop "a mode of utopian thinking: thinking that refuses mere compliance, that looks down roads not yet taken to the shapes of a more fulfilling social order, to more vibrant ways of being in the world" (Greene 1995, 5). This is no easy task in a world "submerged" in bureaucratic practices, yet she was determined to move us beyond education as "simple transmission" (Greene 1995, 3).

Greene's existential commitments forced her to wrestle with the possibilities of hope and despair; yet more often than not, the possibility for deciding, acting, changing, and creating kept the despair at bay. Her concept of the social imagination was intended to provide openings, to create more possibilities, to move us toward a more empowered stance in the world. For Greene, it is through 
critical encounters with a range of art forms that we are provoked to think and act differently. And certainly Greene did provoke countless teachers, artists, and professors-through her teaching and lecturing; through her writing; through her 30 years as Philosopher in Resident at the Lincoln Center Institute for Arts in Education; ${ }^{2}$ through her cofounding of a small high school in New York City focused on the arts and social inquiry. ${ }^{3}$ It was through these actions in the world that Greene embodied her concept of the social imagination. As she says in her book, Releasing the Imagination, the social imagination is "the capacity to invent visions of what should be and what might be in our deficient society, on the streets where we live, in our schools" (Greene 1995, 5). That is clearly what she did herself. It is here that I think it is important to underscore Greene's advocacy of the social dimensions of imagination-imagination that could be transformative-and to discuss how this critical imagination could be enacted as a form of critical pedagogy, especially in the education of teachers.

\section{Greene's Social Imagination in the Education of Teachers}

As an undergraduate at Barnard College in the 1930s, becoming a teacher educator was not on the horizon for Greene, who aspired to write novels. But "life intervened"-particularly the life of a woman and mother. Greene recounted in many of her talks, and again in the Hancock film, how she stumbled into education because it was the only graduate program that offered courses during the day that accommodated her childcare needs. Yet, this "accidental educational tourist" embraced her new field and remained committed to teachers and teacher education for the course of her long, productive career. In fact, in one of her autobiographical tellings she says, "the dimension of education that concerns me most has been teacher education. I have come to that concern out of a background marked by absorption with the liberal arts and by social action as well" (Greene 1995, 1-2).

It was her political experiences as an activist, and her belief in the humanities, that sustained her hope that social change was possible, and it was through the education of teachers that she enacted her progressive hopes.

As noted earlier, Greene understood the limits of critical rationality and of the critical paradigm, especially as manifested in some aspects of traditional philosophy that relied heavily on abstract, decontextualized thinking. With her commitment to the arts and the humanities, Greene employed a multivalent, interdisciplinary frame to complement, even transform, the privileging of a particular kind of knowing. Her existentialist-phenomenological stance asserted that all knowing was the embodied, situated knowing of actual persons in reallife settings. She believed that the social imagination could disrupt instrumental rationality and subvert the authoritarian practices that dominated much of the 
contemporary educational landscape. Greene makes a compelling case for us critical educators when she says:

We who are teachers would have to accommodate ourselves to lives as clerks and functionaries if we did not have in mind a quest for a better state of things for those we teach and for the world we share. It is simply not enough for us to reproduce the way things are. (Greene 1995, 1)

Furthermore, she says:

I hope to connect my own seeking with the strivings of other teachers and teacher educators who are weary of being clerks or technocrats .... I hope to stimulate a kind of silent conversation that may move readers to discover what they have to say once they attend to their own situations, to the actualities of their lives. (Greene 1995, 2)

It is Greene's deep philosophical connection to existentialism, phenomenology, and critical theory-as well as her pragmatic activism-that sustained her hope that people, in community, can think differently, can change their consciousness, can change schools, can change history. For Greene, it was an embedded, embodied consciousness that produced this transformative epistemology; this embodied way of knowing the world in which we live.

\section{“Discovering”" My Critical Pedagogy}

I have learned through pedagogical trial and error that before we can get others to act in the world, especially to act differently in the world, we teachers need to be open to change. And we need to understand why we (and they) need to change. Generally people don't change because they are told to; they need to want it and to claim it as theirs. And they must be ready for it-emotionally, cognitively, and materially. In order to be effective in leading/teaching others toward critical consciousness, I need the courage to incorporate psychological insights, bodily knowledge, aesthetic experience, and even spiritual transformation into my critical analysis of education and society. Greene supports this perspective and offers some thoughts about her "search for a pedagogy:"

If we teachers are to develop a humane and liberating pedagogy, we must feel ourselves to be engaged in a dialectical relation. We are more likely to uncover or be able to interpret what we are experiencing if we can at times recapture some of our own lost spontaneity and some awareness of our own backgrounds, either through communication with children, psychotherapy, or engagement with works of art. Any such engagement may provoke us to recall that rationality itself is grounded in something prerational, prereflective-perhaps in a primordial, perceived landscape (Greene 1995, 52). 
In Releasing the Imagination, Greene speaks of beginnings, and "of how much beginnings have to do with freedom"-freedom to act differently. And this acting differently requires a change of consciousness, and an awareness of possibility. She goes on to claim "that if I and other teachers truly want to provoke students to break through the limits of the conventional and the taken for granted, we ourselves have to experience breaks with what has been established in our own lives; we have to keep arousing ourselves and to begin again" (Greene 1995, 109).

I want to pick up this thread of "break[ing] through the limits of the conventional ... to keep arousing ourselves to begin again" (Greene 1995, 109). The notion of "beginning again" reflects Hannah Arendt's concept of "natality"-where "to act means to take initiative, to begin" (Biesta 2005, 150). But as Gert Biesta, in his work on Arendt 's The Human Condition, reminds us, " because we [teachers] act 'upon beings who are capable of their own actions,' the sphere of human interaction is necessarily 'boundless' and 'ultimately unpredictable”' (Biesta 2005, 150). If we accept "Arendt's understanding of human interaction" [then] "education can never simply be understood as a process where the teacher moulds the student" (Biesta 2005, 151). Biesta asserts that "any account of education has to take into consideration that what is presented by the teacher is not passively taken in, but is actively 'used' by the student" (Biesta 2005, 151). Biesta's view of 'active use' resonates with Dewey's theory of educative experiences, for as Biesta argues, "it is only because the student 'uses' what is presented, that education becomes possible" (Biesta 2005, 151). At the same time, "this use ... introduces unpredictability and transformation" (Biesta 2005, 151).

It is this very possibility of educating others in ways that lead to unpredictability and transformation that encouraged me to incorporate more aesthetic experiences in my teaching. Responding to Dewey and Greene, I also accepted Freire's challenge when he implored teachers to "give creative wings to their imaginations ... [to] demonstrate to students the importance of imagination for life" (Freire 1998, 51).

In many ways, I "began again" as a critical educator through the creation of a course called "The Educational Imagination." Inspired by Greene to make connections "between the aesthetic, the ethical, the intellectual, the existential, and the political" (Gur-Ze'ev 2005, 19), I used the "potency of the arts, to move my students to see things in fresh ways, to de-familiarize experience, to become more 'wide-awake"' (Greene 1973, 2). The course employs Greene's concept of the social imagination to deepen and complicate teachers' understandings of culture, identity, and curriculum. Through the integration of multicultural aesthetic experiences, and an amalgam of feminist and critical pedagogies, students in the course experience the transformative and transgressive power of imagination-the social imagination. Students learn from cultural and social history of marginalized groups in the US and around the globe. They encounter contemporary artists who disrupt and challenge taken-for-granted representations, and they see the critical role the arts and artists can plan in inciting social and educational change. ${ }^{6}$ 
By connecting critical educational and cultural theory to their professional/ practical and personal experiences, my aim is to help the students begin to see the world "as if it could be otherwise." The assignments require them to draw on a range of talents and skills, and move them increasingly out of their comfort zones-their theoretical, psychological, professional, and aesthetic comfort zones. In the course description, I signal that I view the teacher's role as one of empowering students to think critically about their identities, positionalities, and privilege. In doing so, I also indicate that the course is also intended to do the same for them-as teachers and as citizens in a democracy.

Yet in reflecting on the course, I am reminded of the "thin" cultural knowledge many of my students have about art, literature, drama, film, and music. ${ }^{7}$ This poses a pedagogical challenge in terms of how I help them make meaning of what we do.

Greene assists me with this when she says:

Meaning happens in and by means of an encounter with a painting, with a text, with a dance performance. [And yet] the more informed the encounter-by some acquaintance with the medium at hand, some use of critical lenses, and some consciousness of the art world (Danto 1981,5) the more we are likely to notice and the more the work is likely to mean. If questions beat inside us about whether or not something is called good art or bad art, what context has to do with an artwork, and what constitutes good reasons, we are likely to perceive even more (Greene 1995, 139; emphasis added in the second instance).

Grappling with how I facilitate these aesthetic encounters, this "release of the imagination" keeps my interest in teaching the course. Each year it is a creative, educative experience for me-in both planning the curriculum and in experiencing it with my students. Dewey reminds us that learning and meaning-making occurs when a current experience is connected to a prior one: "Imagination is the only gateway through which these meanings can find their way into a present interaction; or rather ... the conscious adjustment of the new and the old is imagination" (Dewey 1934, 272). At the same time, he cautions us that "there is always a gap between the here and now of direct interaction and the past interactions [and] because of this gap, all conscious perception involves a risk; it is a venture into the unknown" (Dewey 1934, 272).

So the pedagogical challenge for me remains one of introducing new, unfamiliar, even transgressive aesthetic experiences to my students in a way to which they can connect from their prior knowledge-which is a big risk because their prior experience with knowledge of "the arts" is so varied, and in some cases, so limited.

At the same time, I struggle with how I insure that it is not, in Dewey's terms, an "anesthetic," or numbing experience, that "prevents them from reaching out, from launching their own inquiries" (Greene 1988, 125). This can happen either by offering all-too-familiar works of art from the conventional canon-shutting 
off their curiosity—or stretching them too far beyond their "ZPD" - shutting them down out of fear of looking ignorant or unsophisticated.

\section{Notes}

1. Drawn from John Dewey, "Search for the Great Community", in The Public and Its Problems, $1^{\text {st }}$ ed. (Athens: Ohio University Press, 1988), 143-84.

2. "Lincoln Center Institute for the Arts in Education," NYC-ARTS: The Complete Guide, http://www.nyc-arts.org/organizations/1992/lincoln-center-institute -for-the-arts-in-education.

3. The High School for Arts, Imagination and Inquiry is one of the many public "small schools" developed in New York City organized around interdisciplinary themes. See "High School for Arts, Imagination and Inquiry," NYC Department of Education, http://schools .nyc.gov/SchoolPortals/03/M299/AboutUs/Overview/default.htm.

4. From Maxine Greene, “Discovering a Pedagogy," In Releasing the Imagination: Essays on Education, the Arts, and Social Change (San Francisco: Jossey-Bass, 1995), 44-59.

5. I was not referring to the classic book by Elliot Eisner when naming the course.

6. Teaching the course for ten years, I used a range of material. However, the core texts for the course remained stable: Dewey's Art as Experience (1934), Greene's Releasing the Imagination (1995), Greene's Variations on a Blue Guitar (2001), Freire's Teachers as Cultural Workers (1998), Cahan and Kocur's Contemporary Art and Multicultural Education (1996), and Joo and Keehn's Rethinking Contemporary Art and Multicultural Education (2011).

7. As context, my "students" are graduate students getting their master's degrees in education; most are practicing teachers; most are women; most are white; most are middle class and live in suburban Connecticut.

\section{REFERENCES}

Bakhtin, Mikhail M. The Dialogic Imagination. Austin: University of Texas Press, 1981. Biesta, Gert. "What Can Critical Pedagogy Learn From Postmodernism." In Critical Theory and Critical Pedagogy Today: Toward a New Critical Language in Education, edited by Ilan Gur-Ze'ev, 142-59. Haifa, Israel: Haifa Press, 2005.

Cahan, Susan, and Kocur Zoya, eds. Contemporary Art and Multicultural Education. New York: Routledge, 1996.

Dewey, John. Experience and Education. New York: Simon and Schuster, 1997. First published 1938 by Kappa Delta Pi.

_-_. Art as Experience. New York: Perigee-Penguin, 1980. First published 1934 by Minton, Balch.

Freire, Paulo. Teachers as Cultural Workers: Letters to Those Who Dare Teach. Boulder, CO: Westview Press, 1998.

Greene, Maxine. The Public School and the Private Vision: A Search for American in Education and Literature. New York: Random House, 1965.

-_- Existential Encounters for Teachers. New York: Random House,1967.

-_- Teacher as Stranger: Educational Philosophy for the Modern Age. Belmont, CA: Wadsworth, 1973. 


\section{W. KoHLI}

- - - Landscapes of Learning. New York: Teachers College Press, 1978.

- - - The Dialectic of Freedom. New York: Teachers College Press, 1988.

- - . Releasing the Imagination: Essays on Education and Social Change. San Francisco: Jossey-Bass, 1995.

-_- Variations on a Blue Guitar: The Lincoln Center Institute Lectures on Aesthetic Education. New York: Teachers College Press, 2001.

Gur-Zeev, Ilan, ed. Critical Theory and Critical Pedagogy Today: Toward a New Critical Language in Education. Haifa, Israel: University of Haifa Press, 2005.

Hancock, Markie. Exclusions and Awakenings: The Life of Maxine Greene. Film. Hancock Productions, 2001.

Joo, Eungie, and Keehn, Joseph, eds. Rethinking Contemporary Art and Multicultural Education. New York: Routledge, 2011.

Wendy Kohli is Professor Emerita at Fairfield University. Email: wkohli@fairfield.edu 